\title{
GLI1 Gene Product
}

National Cancer Institute

\section{Source}

National Cancer Institute. GLI1 Gene Product. NCI Thesaurus. Code C157118.

A protein encoded by the GLI1 gene. 